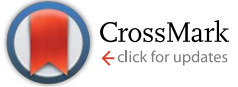

Cite this: RSC Adv., 2017, 7, 7857

Received 7th December 2016 Accepted 16th January 2017

DOI: $10.1039 / c 6 r a 27895 g$

www.rsc.org/advances

\section{Preparation and characterization of spherical $\beta$-cyclodextrin/urea-formaldehyde microcapsules modified by nano-titanium oxide}

\begin{abstract}
Xin Yu, ${ }^{\text {ab }}$ Houjuan Qi, ${ }^{a}$ Zhanhua Huang, ${ }^{* a}$ Bin Zhang ${ }^{a}$ and Shouxin Liu ${ }^{a}$
We successfully prepared novel $\beta$-cyclodextrin/urea-formaldehyde ( $\beta$-CD/UF) microcapsules modified by nano- $\mathrm{TiO}_{2}$ using $\mathrm{KH} 560$ silane coupling agent by in situ polymerization and grafting method. The asprepared $\mathrm{TiO}_{2}-\beta-\mathrm{CD} / \mathrm{UF}$ microcapsules displayed excellent energy storage properties with a melting enthalpy of $154.6 \mathrm{~J} \mathrm{~g}^{-1}$, and the paraffin content in the $\mathrm{TiO}_{2}-\beta-\mathrm{CD} / \mathrm{UF}$ microcapsules was as high as $75.94 \%$, indicating a high energy storage capacity. Nano-titanium oxide was successfully reacted onto the surface of the $\beta$-CD/UF microcapsules using $\mathrm{KH} 560$ by forming new $\mathrm{C}-\mathrm{O}-\mathrm{Si}$ and $\mathrm{Ti}-\mathrm{O}-\mathrm{Si}$ chemical bonds, which was confirmed by FT-IR and XPS technology. Besides, pH played an important role in the encapsulation of phase change paraffin by affecting the curing reaction rate of the shell materials. Also, the thermal decomposition temperature of the $\mathrm{TiO}_{2}-\beta-\mathrm{CD} / \mathrm{UF}$ microcapsules was highly improved by about $90{ }^{\circ} \mathrm{C}$ compared with that of $\beta-\mathrm{CD} / \mathrm{UF}$ microcapsules without treatment by $\mathrm{TiO}_{2}$ nanoparticles, mainly due to the formation of $\mathrm{C}-\mathrm{O}-\mathrm{Si}$ and $\mathrm{Ti}-\mathrm{O}-\mathrm{Si}$ chemical bonds. The as-prepared $\mathrm{TiO}_{2}-\beta-\mathrm{CD} / \mathrm{UF}$ microcapsules in this experiment might be used as an effective and potential media for energy storage.
\end{abstract}

\section{Introduction}

Studies on phase change materials (PCMs) are attracting more attentions nowadays because of their potential application in buildings, textiles and thermoelectric materials. ${ }^{1-5}$ In general, PCMs are highly expected to release or store latent energy during the physical phase transition process yet leaving no pollution in the ambient environment. ${ }^{6}$ Thus, it is very intriguing to explore the stable and high enthalpy PCMs. Besides, highly desired PCMs should have some other excellent properties, such as repeated usage and being environmentally friendly. ${ }^{7-9}$ It would be profitable to explore suitable PCMs and effective encapsulation technology for fabricating phase change storage materials. Phase change microcapsules are an important type of PCMs, which could offer an enclosed space, much like containers, to restrict the flow ability of the encapsulated materials, such as paraffin, $n$-heptadecane and epoxy resins. ${ }^{4,10-12}$ Until now, there are many methods for preparing phase change microcapsules for energy storage, such as in situ polymerization, ${ }^{13}$ interfacial polymerization, ${ }^{14}$ sol-gel method, ${ }^{15}$ and etc. However, many PCMs always suffered from some disadvantages, such as the poor strength property, low encapsulation efficiency and low decomposition temperatures., ${ }^{5,16-18}$

${ }^{a}$ Key Laboratory of Bio-based Material Science and Technology of Ministry of Education, Northeast Forestry University, Harbin 150040, China.E-mail: nefuhzh@ nefu.cn

${ }^{b}$ School of Chemistry and Chemical Engineering, Harbin Institute of Technology, Harbin 150001, P. R. China
And some formaldehyde-contained resin-based PCMs did great harm to the ambient environment by releasing toxic gas. Generally, some organic or inorganic materials, such as cellulose, melamine, titanium oxide or silicon dioxide, could be used for decreasing the existence of free formaldehyde and enhancing the strength of the shell materials for high encapsulation efficiency. ${ }^{19-21}$ And thus, nano-titanium oxide and $\beta$ cyclodextrin modified urea-formaldehyde paraffin microcapsules are highly expected to have high encapsulation efficiency and little formaldehyde releasing property.

In this work, inorganic $\mathrm{TiO}_{2}$ nanoparticles were used to modify the spherical $\beta$-CD/UF paraffin microcapsules by grafting method using KH560 silane coupling agent to enhance the strength of the $\mathrm{TiO}_{2}-\beta$-CD/UF microcapsules and decrease the free formaldehyde in the shell materials. Besides, the influences of nano- $\mathrm{TiO}_{2}$ and $\mathrm{pH}$ on the melting enthalpy and thermal stability of the $\mathrm{TiO}_{2}-\beta$-CD/UF microcapsules were investigated by DSC and TGA instruments in detail. Besides, the possible formation procedures of the spherical $\mathrm{TiO}_{2}-\beta-\mathrm{CD} / \mathrm{UF}$ microcapsules were also proposed in the Experimental section.

\section{Experimental}

\section{Preparation of $\mathrm{TiO}_{2}-\beta$-CD/UF microcapsules}

All the raw materials were commercially available and used directly without further purification in this experiment. In a typical procedure, $2.5 \mathrm{~g}$ urea, $6.24 \mathrm{~mL}$ formaldehyde (37 wt\%) and deionized water were mixed with $\mathrm{pH}$ adjusted to $\sim 8-9$ by triethanolamine. The mixture was heated to $\sim 70{ }^{\circ} \mathrm{C}$ for $60 \mathrm{~min}$ 


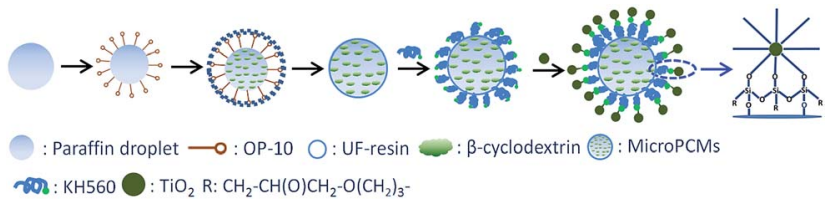

Scheme 1 The schematic illustration of the formation of $\mathrm{TiO}_{2}-\beta-\mathrm{CD} /$ UF microcapsules.

with stirring, and then $\beta$-cyclodextrin was added into the mixture and stirred to form $\beta$-CD-UF solution.

OP-10, paraffin, deionized water and cyclohexane were mixed by stirring to form oil/water emulsion for $\sim 15 \mathrm{~min}$. $\beta$-CDUF solution, ammonium chloride and resorcin were added into the paraffin dispersion by dropping and heated to $\sim 50-60{ }^{\circ} \mathrm{C}$ with stirring for $\sim 55 \mathrm{~min}$. The nano- $\mathrm{TiO}_{2}$ treated by $\mathrm{KH} 560$ was added into the reaction system and reacted for $120 \mathrm{~min} .{ }^{22}$ The as-prepared $\mathrm{TiO}_{2}-\beta$-CD/UF microcapsules were cooled down, washed with deionized water, dried for $48 \mathrm{~h}$. The samples with the dosage of $0 \%, 2.5 \%, 5 \%, 7.5 \%$ and $10 \%\left(\mathrm{TiO}_{2}\right.$ to micro PCMs) were denoted as A0, A1, A2, A3, A4, and A5, respectively. Scheme 1 showed the schematic illustration of the formation of spherical $\mathrm{TiO}_{2}-\beta$-CD/UF microcapsules in this experiment.

\section{Characterization}

The morphology of the as-prepared $\mathrm{TiO}_{2}-\beta-\mathrm{CD} / \mathrm{UF}$ microcapsules was investigated using FEI QUANTA 200 scanning electronic microscope (SEM) (USA) and JEM-2100 transmission electron microscope (TEM) (Japan) at $200 \mathrm{kV}$. The chemical structures and element states of the $\mathrm{TiO}_{2}-\beta-\mathrm{CD} / \mathrm{UF}$ microcapsules were studied on a Thermo Fisher Nicolet 6700 FT-IR spectrometer (USA) and a K-Alpha X-ray photoelectron spectrometer (Thermo fisher Scientific Company, USA). The crystal structure of the $\mathrm{TiO}_{2}-\beta$-CD/UF microcapsules was studied by a Japanese Rigaku D/MAX 2200 X-ray diffractometer (XRD) (Japan). The melting enthalpy and the thermal stability were studied on a TA Q20 differential scanning calorimeter (DSC) by a heating rate of $5{ }^{\circ} \mathrm{C} \mathrm{min}{ }^{-1}$ from $10{ }^{\circ} \mathrm{C}$ to $65{ }^{\circ} \mathrm{C}$ and TA Q50 thermogravimetric analyzer (TGA) (USA) in the nitrogen

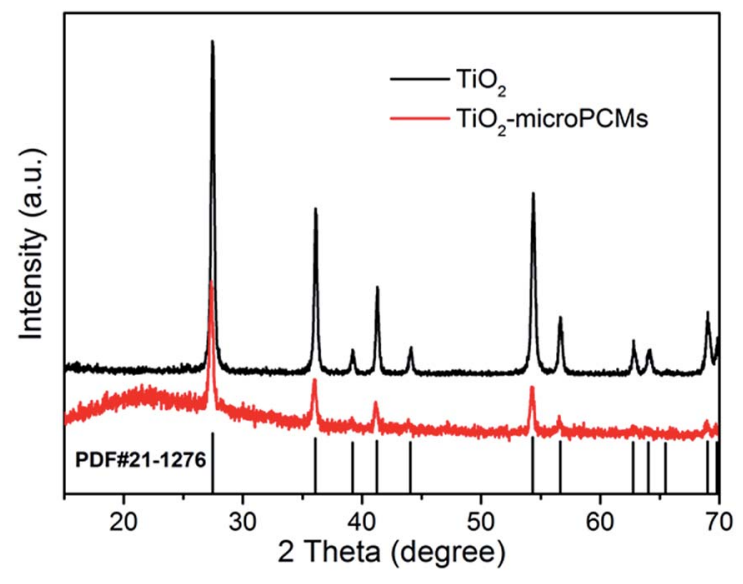

Fig. 1 XRD patterns of $\mathrm{TiO}_{2}$ and $\mathrm{TiO}_{2}-\beta-\mathrm{CD} / \mathrm{UF}$ microcapsules.

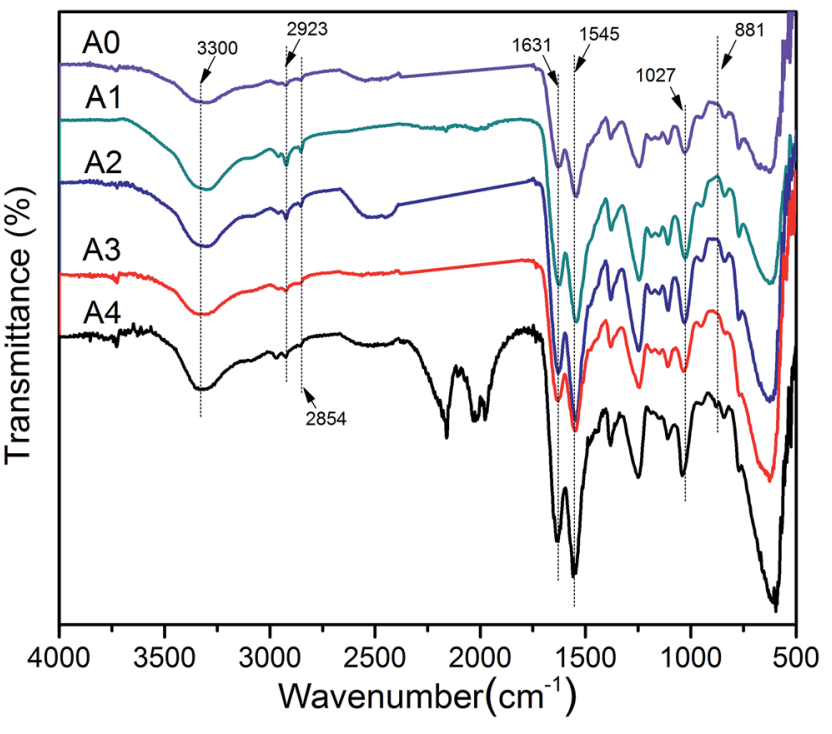

Fig. 2 FT-IR spectra of the $\mathrm{TiO}_{2}-\beta-\mathrm{CD} / \mathrm{UF}$ microcapsules.

atmosphere. The content of the paraffin could be measured according to the following equation based on the melting enthalpy measured by DSC instrument,

$$
\text { Paraffin }(\%)=\Delta H / \Delta H_{0} \times 100 \%
$$
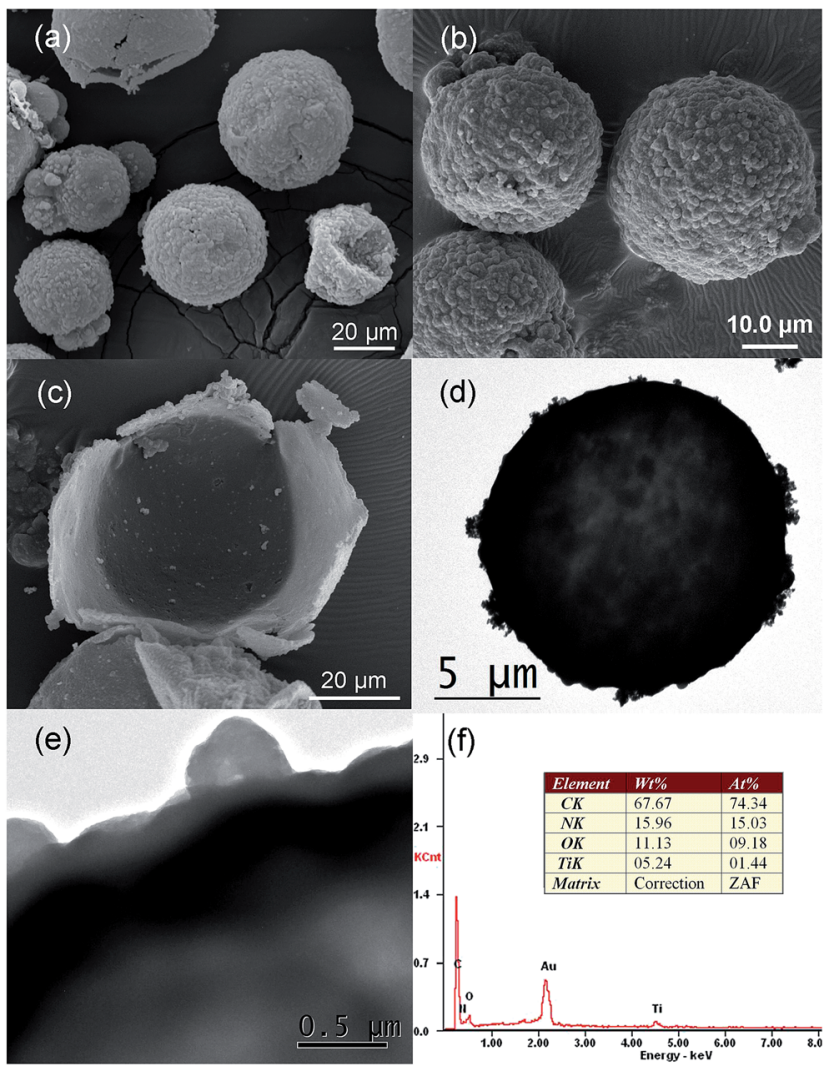

(f)

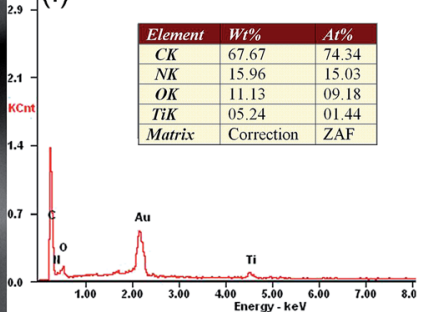

Fig. 3 Typical SEM images ( $a-c)$, TEM images ( $d$ and e) and the EDS spectrum (f) of the as-prepared $\mathrm{TiO}_{2}-\beta-\mathrm{CD} / \mathrm{UF}$ microcapsules. 
where paraffin (\%) is the content of paraffin within the PCMs, $\Delta H$ is melting enthalpy of the micro PCMs, and $\Delta H_{0}$ is melting enthalpy of phase change paraffin. ${ }^{23-25}$

\section{Results and discussion}

Fig. 1 showed the XRD patterns of the purchased rutile $\mathrm{TiO}_{2}$ and $\mathrm{TiO}_{2}-\beta-\mathrm{CD} / \mathrm{UF}$ microcapsules. The as-prepared $\mathrm{TiO}_{2}-\beta-\mathrm{CD} / \mathrm{UF}$ microcapsules displayed several distinct characteristic diffraction peaks around at $27.45^{\circ}, 36.09^{\circ}, 39.19^{\circ}, 41.23^{\circ}, 44.05^{\circ}$, $54.32^{\circ}, 56.64^{\circ}, 62.74^{\circ}, 64.04^{\circ}$ and $69.01^{\circ}$, which could be assigned to the (110), (101), (200) (111), (210), (211), (220), (002), (310) and (301) planes of the rutile $\mathrm{TiO}_{2}$ (JCPDS no. 21-1276), respectively. That is, rutile nano- $\mathrm{TiO}_{2}$ was successfully reacted onto the surface of the $\beta$-CD/UF microcapsules by forming new Ti-O-Si chemical bond using KH560 silane coupling agent, which was much like the surface modification of $\mathrm{NdFe}_{12} \mathrm{~N}_{x}$ or quartz sand by KH550 silane coupling agent. ${ }^{26,27}$ The XRD patterns of $\mathrm{TiO}_{2}-\beta-\mathrm{CD} / \mathrm{UF}$ microcapsules showed no other characteristic diffraction except that of nano- $\mathrm{TiO}_{2}$, which confirmed the poor crystallinity of the $\beta-\mathrm{CD} / \mathrm{UF}$ microcapsules phase change material without loading nano- $\mathrm{TiO}_{2}$ particles.

FT-IR spectra of the $\beta$-CD/UF microcapsules and $\mathrm{TiO}_{2}-\beta-\mathrm{CD} /$ UF microcapsules phase change materials are shown in Fig. 2. The spectra of A0, A1, A2, A3 and A4 samples showed a strong, broad absorption band at $\sim 3300 \mathrm{~cm}^{-1}$, which was assigned to the $-\mathrm{OH}$ stretching vibrations of cyclodextrin and absorbed water molecule..$^{28,29}$ The peaks at $2923 \mathrm{~cm}^{-1}$ and $2854 \mathrm{~cm}^{-1}$ corresponded to the asymmetric and symmetric $-\mathrm{CH}_{2}$ stretching vibration, ${ }^{17,30}$ and the peaks of samples A1, A2, A3 and A4 were stronger than that of A0, presumably due to the formation of $-\mathrm{CH}_{2}$ after cross-linking reaction between $\beta$-cyclodextrin and UF pre-polymer. ${ }^{31}$ The absorption peak at $1631 \mathrm{~cm}^{-1}$ and 1545 $\mathrm{cm}^{-1}$ were attributed to the $\mathrm{C}-\mathrm{O}$ stretching vibration and $\mathrm{C}-\mathrm{N}$ stretching vibration. ${ }^{29}$ The peak at $1027 \mathrm{~cm}^{-1}$ corresponded to C-O-C stretching with an increase of the peak intensity accompanied by the amount increase of $\beta$-cyclodextrin. ${ }^{32,33}$ The peak at $881 \mathrm{~cm}^{-1}$ might be corresponded to Ti-O-Ti stretching vibration. Comparing with samples A0 and A1, A2, A3, A4, we could conclude that $\mathrm{TiO}_{2}-\beta-\mathrm{CD} / \mathrm{UF}$ microcapsules were
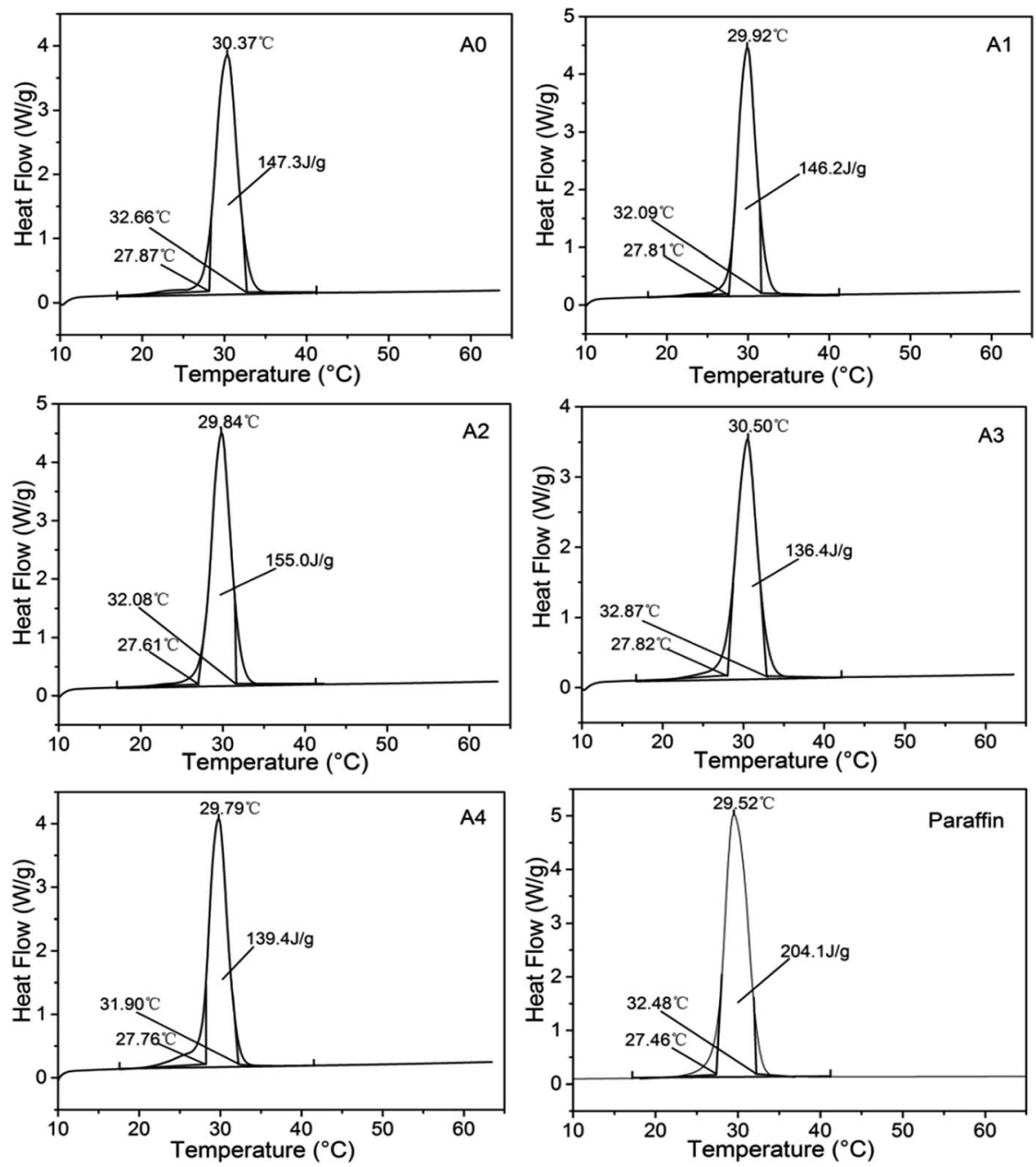

Fig. 4 The DSC curves of paraffin and $\mathrm{TiO}_{2}-\beta-\mathrm{CD} / \mathrm{UF}$ microcapsules. 

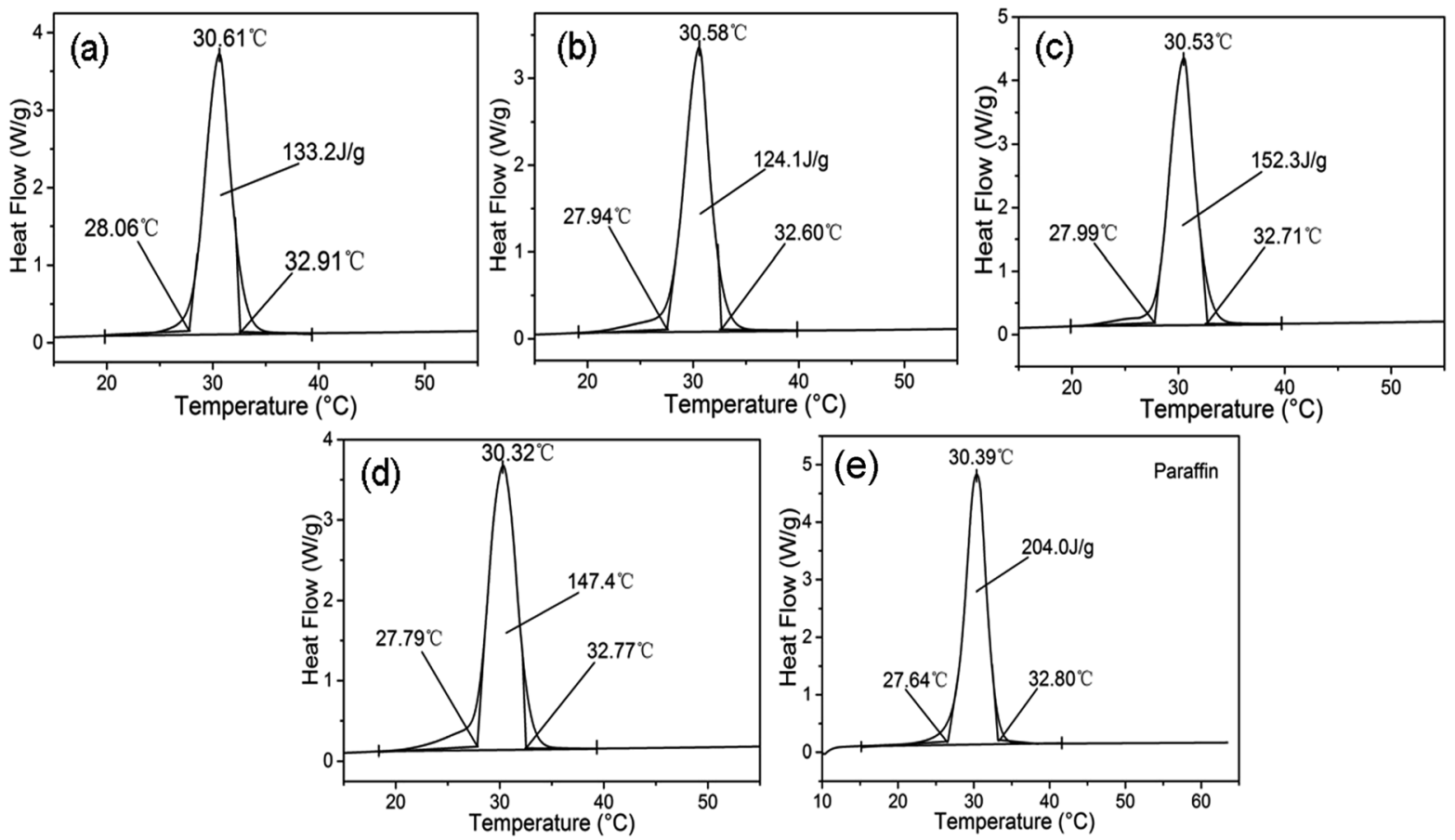

Fig. 5 Effect of $\mathrm{pH}$ on the melting enthalpy of the $\mathrm{TiO}_{2}-\beta-\mathrm{CD} / \mathrm{UF}$ microcapsules: (a) 2.5, (b) 3.0, (c) 3.5, (d) 4.0.

successfully fabricated by forming new Ti-O-Si chemical bond using KH560 silane coupling agent.

Fig. 3 showed the SEM images (a-c), TEM images (d and e) and the energy spectrum (f) of $\mathrm{TiO}_{2}-\beta-\mathrm{CD} / \mathrm{UF}$ microcapsules. As seen in Fig. 3(a) and (b), the as-prepared $\mathrm{TiO}_{2}-\beta-\mathrm{CD} / \mathrm{UF}$ microcapsules were spherical with relatively high dispersion yet nonuniform particle size, whose morphology was much like the encapsulated phase change materials reported in the literatures. ${ }^{29,34}$ And the surfaces of $\mathrm{TiO}_{2}-\beta-\mathrm{CD} / \mathrm{UF}$ microcapsules were not smooth, mainly because of the modification by nano- $\mathrm{TiO}_{2}$. The broken microcapsules displayed in Fig. 3(c) clearly revealed the typical core-shell structure of $\mathrm{TiO}_{2}-\beta-\mathrm{CD} / \mathrm{UF}$ microcapsules, which offered a fixed container for the encapsulation of paraffin, and the paraffin was confined in the $\mathrm{TiO}_{2}{ }^{-}$ cyclodextrin/UF microcapsules with weak flowability, ${ }^{35}$ which might greatly influence the melting temperatures of the asprepared $\mathrm{TiO}_{2}-\beta$-CD/UF microcapsules phase change material. ${ }^{36}$ Fig. $3(\mathrm{~d})$ and (e) showed the TEM images of $\mathrm{TiO}_{2}{ }^{-}$
cyclodextrin/UF microcapsules, which were the core-shell structure and filled with paraffin. The surface of the as-prepared sample was not smooth, which was consistent with SEM result. As shown in Fig. $3(\mathrm{f})$, the as-prepared $\mathrm{TiO}_{2}-\beta-\mathrm{CD} / \mathrm{UF}$ microcapsules were composed of $\mathrm{C}, \mathrm{N}, \mathrm{O}$ and Ti elements, which also indicated that $\mathrm{TiO}_{2}-\beta-\mathrm{CD} / \mathrm{UF}$ microcapsules were successfully prepared in this experiment.

The DSC curves of the $\mathrm{TiO}_{2}-\beta$-CD/UF microcapsules with different dosage of nano- $\mathrm{TiO}_{2}$ were shown in Fig. 4 . The melting temperature and enthalpy of phase change paraffin are $29.52^{\circ} \mathrm{C}$ and $204.1 \mathrm{~J} \mathrm{~g}^{-1}$. The melting temperatures of the samples $\mathrm{A} 0$, $\mathrm{A} 1, \mathrm{~A} 2, \mathrm{~A} 3$ and $\mathrm{A} 4$ were $30.37^{\circ} \mathrm{C}, 29.92{ }^{\circ} \mathrm{C}, 29.84^{\circ} \mathrm{C}, 30.50^{\circ} \mathrm{C}$ and $29.79{ }^{\circ} \mathrm{C}$, and the melting enthalpy of samples A0, A1, A2, A3 and $\mathrm{A} 4$ were $147.3 \mathrm{~J} \mathrm{~g}^{-1}, 146.2 \mathrm{~J} \mathrm{~g}^{-1}, 155.0 \mathrm{~J} \mathrm{~g}^{-1}, 136.4 \mathrm{~J} \mathrm{~g}^{-1}$ and $139.4 \mathrm{~J} \mathrm{~g}^{-1}$, respectively. The melting enthalpy of the $\mathrm{TiO}_{2}-\beta$ $\mathrm{CD} / \mathrm{UF}$ microcapsules in this experiment was much higher than those of phase change materials in the literatures. ${ }^{37,38}$ The melting enthalpy of sample A2 was higher than those of

Table 1 Recent studies on phase change materials for energy storage

\begin{tabular}{|c|c|c|c|c|}
\hline Energy storage materials (ESMs) & $\Delta H_{\mathrm{ESMs}}\left(\mathrm{J} \mathrm{g}^{-1}\right)$ & $\Delta H_{\mathrm{PCMs}}\left(\mathrm{J} \mathrm{g}^{-1}\right)$ & PCMs & References (year) \\
\hline CMC-MF/paraffin & 83.46 & 135.8 & Paraffin & $(2013)^{29}$ \\
\hline PMMA/n-octacosane & 86.4 & 201.6 & $n$-Octacosane & $(2009)^{11}$ \\
\hline PMMA/eicosane & 84.2 & 242.8 & Eicosane & $(2011)^{34}$ \\
\hline $\mathrm{PMMA}-\mathrm{SiO}_{2}$ paraffin & 71 & 121 & Paraffin & $(2015)^{19}$ \\
\hline PMMA/n-dodecanol & 98.8 & 248 & $n$-Dodecanol & $(2012)^{35}$ \\
\hline $\mathrm{OPP} / \mathrm{SA}$ & 111 & 189.36 & Stearic acid & $(2015)^{46}$ \\
\hline $\mathrm{TiO}_{2}-$ micro-PCMs & 155.0 & 204.10 & Paraffin & This work \\
\hline
\end{tabular}



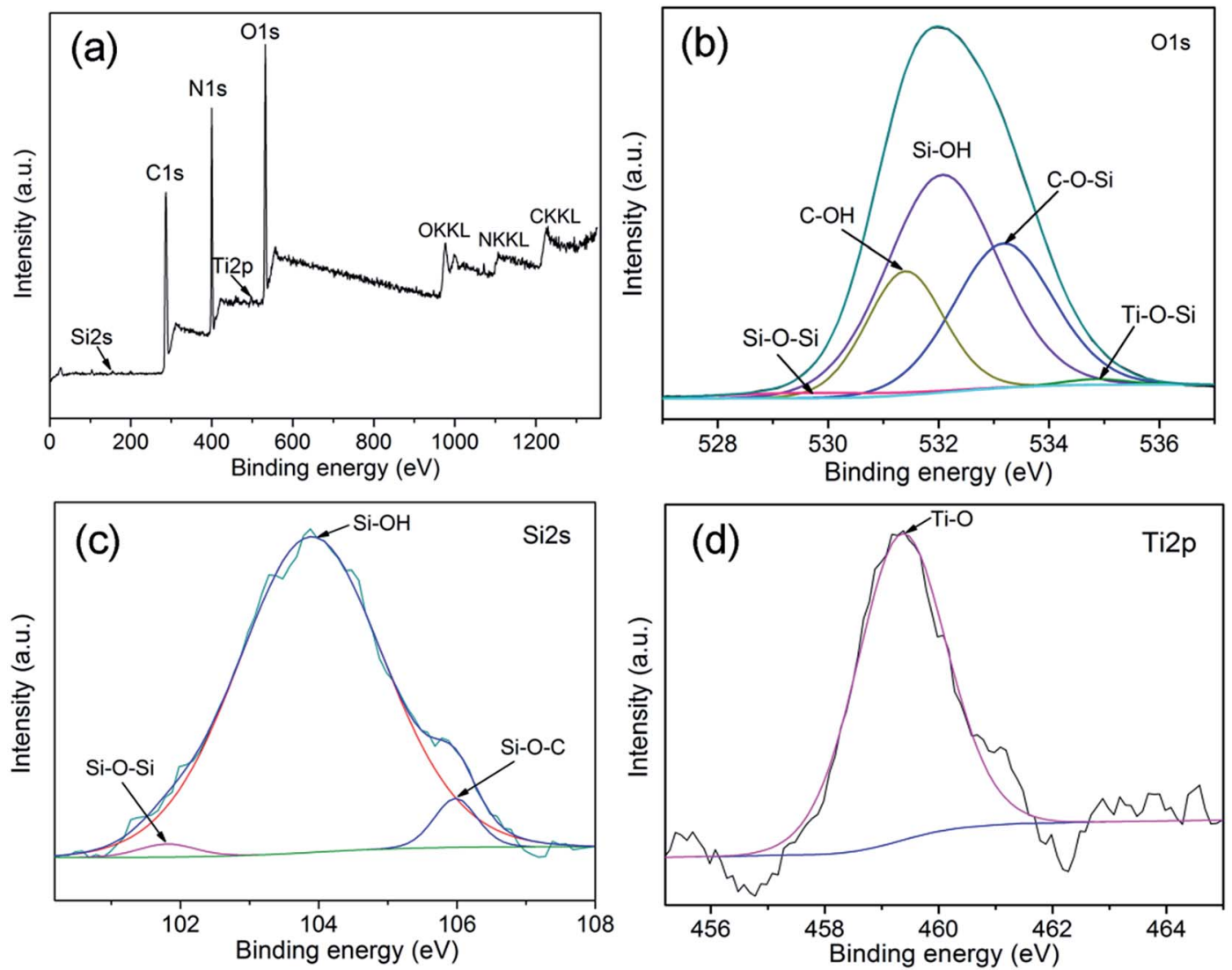

Fig. 6 XPS spectra of the $\mathrm{TiO}_{2}-\beta-\mathrm{CD} / \mathrm{UF}$ microcapsules: (a) survey, (b) O1s, (c) Si2p and (d) Ti2p.

samples A1, A3, and A4, probably because of nano- $\mathrm{TiO}_{2}$ and $\beta$ cyclodextrin increasing the encapsulation efficiency of ureaformaldehyde resin. The sample A2 displayed only one endothermic peak, and the melting temperature was at about $29.84{ }^{\circ} \mathrm{C}$. In general, the phase change paraffin gradually became disordered rotator phase during the heating process, yet no new chemical bonds formation between $\beta-\mathrm{CD} / \mathrm{UF}$ resin and paraffin, much like microencapsulated paraffin@SiO phase change composite. ${ }^{36}$ However, when the dosage of nano$\mathrm{TiO}_{2}$ exceeded $7.5 \%$, the encapsulation of phase change paraffin was affected, resulting in the decline of the melting enthalpy for samples A3 and A4. The possible reason was that nano- $\mathrm{TiO}_{2}$ was in favor for increasing the strength of the microcapsules and the degree of cross-linking reaction to reduce free-formaldehyde concentration yet detrimental for the curing reaction rate, as depicted in the samples A3 and A4. And the content of paraffin in the microcapsules could reach as high as $\sim 75.94 \%$ according to melting enthalpy of $\mathrm{TiO}_{2}-\beta$-CD/UF microcapsules compared with that of paraffin (eqn (1)) by DSC measurement, indicating the as-prepared $\mathrm{TiO}_{2}-\beta$-CD/UF microcapsules was a promising and effective energy storage media. ${ }^{39,40}$

We also investigated the effects of $\mathrm{pH}$ on the encapsulation of paraffin within the $\mathrm{TiO}_{2}-\beta$-CD/UF microcapsules by evaluating the melting enthalpy of the as-prepared $\mathrm{TiO}_{2}-\beta-\mathrm{CD} / \mathrm{UF}$ microcapsules. As shown in Fig. 5 , the $\mathrm{TiO}_{2}-\beta-\mathrm{CD} / \mathrm{UF}$ microcapsules showed the similar endothermic peaks during the solid-liquid melting process. The melting temperatures of samples (a), (b), (c) and (d) were $30.61{ }^{\circ} \mathrm{C}, 30.58{ }^{\circ} \mathrm{C}, 30.53$, and $30.32{ }^{\circ} \mathrm{C}$, which was very close to that of pure paraffin..$^{27,41,42}$ The enthalpy of samples (a), (b), (c) and (d) were $133.2 \mathrm{~J} \mathrm{~g}^{-1}, 124.1 \mathrm{~J}$ $\mathrm{g}^{-1}, 152.3 \mathrm{~J} \mathrm{~g}^{-1}$ and $147.4 \mathrm{~J} \mathrm{~g}^{-1}$, which were much lower than that of pure phase change paraffin $\left(204.0 \mathrm{~J} \mathrm{~g}^{-1}\right)$, yet higher than those of PCMs in the Table 1, showing its great advantages of the as-prepared $\mathrm{TiO}_{2}-\beta$-CD/UF microcapsules. As seen in Fig. 5 ,

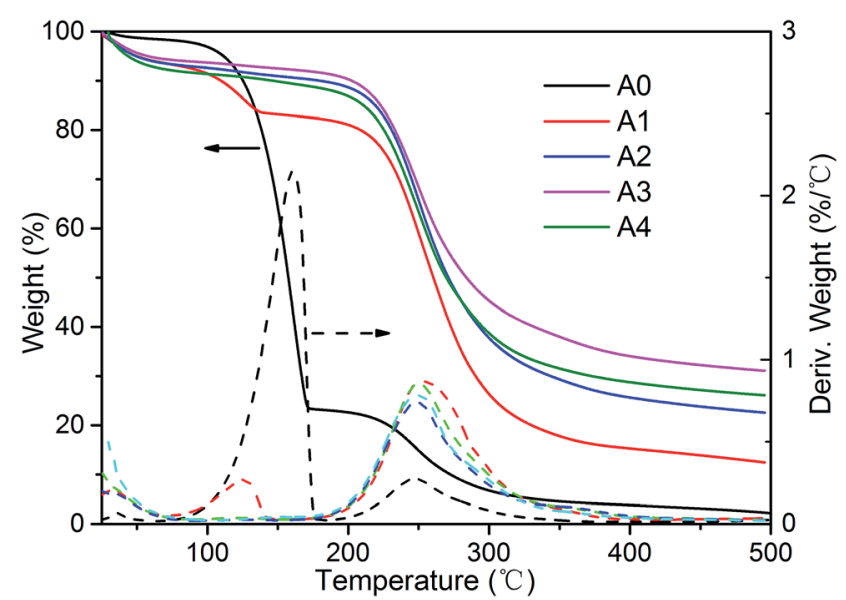

Fig. 7 TGA and TGA curves of the $\beta$-CD/UF microcapsules and $\mathrm{TiO}_{2}-$ $\beta$-CD/UF microcapsules. 
when $\mathrm{pH}$ exceeded 3.0, the melting enthalpy of the samples (c) and (d) were much higher than those of the samples (a) and (b), presumably mainly due to the suitable curing reaction rate of the $\beta$-CD/UF resin and high encapsulation efficiency. And thus, $\mathrm{pH}$ played an important role in forming the core-shell microencapsulation phase change materials..$^{13,29,33,43}$ Besides, the content of paraffin in the $\mathrm{TiO}_{2}-\beta-\mathrm{CD} / \mathrm{UF}$ microcapsules could reach up to $74.66 \%$, which also indicated the $\mathrm{TiO}_{2}-\beta-\mathrm{CD} / \mathrm{UF}$ microcapsules might be used in energy regulating field.

We also investigated the chemical composition and element states of the $\mathrm{TiO}_{2}-\beta$-CD/UF microcapsules by XPS technology. As shown in Fig. 6(a), the as-prepared $\mathrm{TiO}_{2}-\beta-\mathrm{CD} / \mathrm{UF}$ microcapsules were composed of C, N, O, Si and Ti elements. Fig. 6(b) displayed the O1s XPS spectra of $\mathrm{TiO}_{2}-\beta-\mathrm{CD} / \mathrm{UF}$ microcapsules. The fitting peaks of O1s spectra at $529.89 \mathrm{eV}, 531.45 \mathrm{eV}$, $532.09 \mathrm{eV}, 533.24 \mathrm{eV}$ and $534.95 \mathrm{eV}$ were assigned to oxygen atoms in the $\mathrm{Si}-\mathrm{O}-\mathrm{Si}, \mathrm{C}-\mathrm{OH}, \mathrm{Si}-\mathrm{OH}, \mathrm{C}-\mathrm{O}-\mathrm{Si}$ and $\mathrm{Ti}-\mathrm{O}-\mathrm{Si}$ chemical bonds, ${ }^{30}$ further confirming the formation of $\mathrm{C}-\mathrm{O}-\mathrm{Si}$ and $\mathrm{Ti}-\mathrm{O}-\mathrm{Si}$ chemical bonds. We might conclude that nano$\mathrm{TiO}_{2}$ successfully reacted onto the surface of the $\beta-\mathrm{CD} / \mathrm{UF}$ microcapsules using $\mathrm{KH} 560$ by forming $\mathrm{C}-\mathrm{O}-\mathrm{Si}$ and $\mathrm{Ti}-\mathrm{O}-\mathrm{Si}$ chemical bonds. ${ }^{30,47}$ The peaks of Si2p spectra at $101.83 \mathrm{eV}$, $103.89 \mathrm{eV}$ and $105.99 \mathrm{eV}$ were assigned to silicon atoms in the $\mathrm{Si}-\mathrm{O}-\mathrm{Si}, \mathrm{Si}-\mathrm{OH}$ and $\mathrm{Si}-\mathrm{O}-\mathrm{C}$ chemical bonds. ${ }^{27,30,48-50}$ The peak of Ti2p spectra at $459.33 \mathrm{eV}$ corresponded to titanium atoms in the Ti-O-Ti chemical bond, ${ }^{51}$ which was consistent with XRD and FT-IR results. It could be concluded that the $\mathrm{TiO}_{2}-\beta-\mathrm{CD} / \mathrm{UF}$ microcapsules were successfully fabricated by forming $\mathrm{C}-\mathrm{Si}-\mathrm{O}$ and $\mathrm{Si}-\mathrm{O}-\mathrm{Ti}$ chemical bonds using $\mathrm{KH} 560$ silane coupling agent.

TGA and DTG curves of the $\beta$-CD/UF microcapsules and $\mathrm{TiO}_{2}-\beta-\mathrm{CD} / \mathrm{UF}$ microcapsules with different dosage of $\mathrm{TiO}_{2}$ were displayed in Fig. 7. The $\beta$-CD/UF microcapsules without $\mathrm{TiO}_{2}$ treatment lost its weight rapidly with two decomposition process from room temperature to $500{ }^{\circ} \mathrm{C}$, as was shown in the DTG curves of the sample A0. When the dosage of $\mathrm{TiO}_{2}$ was $2.5 \%$, the DTG curve of the sample A1 had a similar DTG curve with two decomposition process, which indicated the A0 and A1 samples had similar decomposition process. However, when the dosage of $\mathrm{TiO}_{2}$ reached $5 \%$, the TGA curves of the A2 sample had a different decomposition process compared with the samples $\mathrm{A} 0$ and $\mathrm{A} 1$, which indicated that the content of $\mathrm{Si}-\mathrm{O}-\mathrm{Ti}$ chemical bond increased markedly with the increase of nano$\mathrm{TiO}_{2}$, which greatly changed the decomposition process of the $\mathrm{TiO}_{2}-\beta-\mathrm{CD} / \mathrm{UF}$ microcapsules phase change material. ${ }^{52,53}$ The thermal decomposition temperatures of the samples $\mathrm{A} 0, \mathrm{~A} 1, \mathrm{~A} 2$, A3 and A4 were $\sim 131.14^{\circ} \mathrm{C}, 224.77^{\circ} \mathrm{C}, 220.66^{\circ} \mathrm{C}, 223.38^{\circ} \mathrm{C}$ and $219.49^{\circ} \mathrm{C}$, respectively. It could be speculated that the increase of the thermal decomposition temperatures of $\mathrm{TiO}_{2}-\beta-\mathrm{CD} / \mathrm{UF}$ microcapsules were mainly due to the formation of the new Si-O-Ti chemical bond, which was also in good consistent of the XRD and XPS results.

\section{Conclusions}

We successfully prepared a series of novel $\mathrm{TiO}_{2}-\beta-\mathrm{CD} / \mathrm{UF}$ microcapsules by in situ polymerization and grafting reaction using KH560 silane coupling agent. The results showed that nano- $\mathrm{TiO}_{2}$ successfully reacted on the surface of the $\beta-\mathrm{CD} / \mathrm{UF}$ microcapsules by forming $\mathrm{C}-\mathrm{O}-\mathrm{Si}$ and $\mathrm{Ti}-\mathrm{O}-\mathrm{Si}$ chemical bonds, which highly enhanced the decomposition temperature of $\mathrm{TiO}_{2}-\beta$-CD/UF microcapsules by about $90{ }^{\circ} \mathrm{C}$, showing great advantages compared with that of the $\beta-\mathrm{CD} / \mathrm{UF}$ microcapsules. The melting enthalpy of the $\mathrm{TiO}_{2}-\beta-\mathrm{CD} / \mathrm{UF}$ microcapsules could reach up to $154.6 \mathrm{~J} \mathrm{~g}^{-1}$ and the paraffin content in the $\mathrm{TiO}_{2}-\beta$ CD/UF microcapsules was up to $75.94 \%$ according to the melting enthalpy measured by DSC instrument. Besides, $\mathrm{pH}$ also had great influences on the curing reaction rate in the formation of spherical $\mathrm{TiO}_{2}-\beta-\mathrm{CD} / \mathrm{UF}$ microcapsules, directly affecting the melting enthalpy of the $\mathrm{TiO}_{2}-\beta-\mathrm{CD} / \mathrm{UF}$ microcapsules. The as-prepared $\mathrm{TiO}_{2}-\beta-\mathrm{CD} / \mathrm{UF}$ microcapsules in this experiment might be used an effective energy regulating media for solar energy conversion.

\section{Acknowledgements}

The authors would like to thank the National Natural Science Foundation of China (No. 31670592); the Central University Basic Scientific Research Project of China (No. 2572017EB03); and the Research Funds for the Returned People of Heilongjiang Province (No. LC2016008).

\section{Notes and references}

1 D. Lencer, M. Salinga, B. Grabowski, T. Hickel, J. Neugebauer and M. Wuttig, Nat. Mater., 2008, 7, 972-977.

2 Y. Konuklu, M. Ostry, H. O. Paksoy and P. Charvat, Energy and Buildings, 2015, 106, 134-155.

3 A. Jamekhorshid, S. M. Sadrameli and M. Farid, Renewable Sustainable Energy Rev., 2014, 31, 531-542.

4 A. Sari, C. Alkan and A. Karaipekli, Appl. Energy, 2010, 87, 1529-1534.

5 S. Mondal, Appl. Therm. Eng., 2008, 28, 1536-1550.

6 M. M. Farid, A. M. Khudhair, S. A. K. Razack and S. Al-Hallaj, Energy Convers. Manage., 2004, 45, 1597-1615.

7 D. Zhou, C. Y. Zhao and Y. Tian, Appl. Energy, 2012, 92, 593605.

8 T. Do, Y. G. Ko, Y. Chun and U. S. Choi, ACS Sustainable Chem. Eng., 2015, 3, 2874-2881.

9 S. Wi, J. Seo, S.-G. Jeong, S. J. Chang, Y. Kang and S. Kim, Sol. Energy Mater. Sol. Cells, 2015, 143, 168-173.

10 B. Xie, G. Liu, S. Jiang, Y. Zhao and D. Wang, J. Phys. Chem. B, 2008, 112, 13310-13315.

11 A. Sari, C. Alkan, A. Karaipekli and O. Uzun, Sol. Energy, 2009, 83, 1757-1763.

12 L. Yuan, G.-Z. Liang, J.-Q. Xie, J. Guo and L. Li, Polym. Degrad. Stab., 2006, 91, 2300-2306.

13 M. Zuo, T. Liu, J. Han, Y. Tang, F. Yao, Y. Yuan and Z. Qian, Chem. Eng. J., 2014, 249, 27-33.

14 J. S. Cho, A. Kwon and C. G. Cho, Colloid Polym. Sci., 2002, 280, 260-266.

15 S. T. Latibari, M. Mehrali, M. Mehrali, A. B. M. Afifi, T. M. I. Mahlia, A. R. Akhiani and H. S. C. Metselaar, Energy, 2015, 85, 635-644. 
16 Q.-x. Zhang, J.-h. Chen, H.-b. Lu, W. Tang, Y. Lu and Y.-z. Gao, Acta Polym. Sin., 2015, 692-698.

17 Y. Zhu, S. Liang, K. Chen, X. Gao, P. Chang, C. Tian, J. Wang and Y. Huang, Energy Convers. Manage., 2015, 105, 908-917.

18 S.-s. Chen, J. Hu, L. Gao, Y. Zhou, S.-m. Peng, J.-l. He and Z.-m. Dang, RSC Adv., 2016, 6, 33599-33605.

19 J. Shi, X. Wu, X. Fu and R. Sun, Thermochim. Acta, 2015, 617, 90-94.

20 Y. Konuklu, H. O. Paksoy and M. Unal, Appl. Energy, 2015, 150, 335-340.

21 F. He, X. Wang and D. Wu, Energy, 2014, 67, 223-233.

22 M. Xu, S. Lin, S. Gong and Z. Yang, Adv. Mater. Res., 2012, 399-401, 688-692.

23 K. Tumirah, M. Z. Hussein, Z. Zulkarnain and R. Rafeadah, Energy, 2014, 66, 881-890.

24 Y. Konuklu, H. O. Paksoy, M. Unal and S. Konuklu, Energy Convers. Manage., 2014, 80, 382-390.

25 A. Sari, C. Alkan and C. Bilgin, Appl. Energy, 2014, 136, 217227.

26 H. Chen, J. Zheng, L. Qiao, Y. Ying, L. Jiang and S. Che, Adv. Powder Technol., 2015, 26, 618-621.

27 B. Wei, Q. Chang, C. Bao, L. Dai, G. Zhang and F. Wu, Colloids Surf., A, 2013, 434, 276-280.

28 B. Tang, L. Wang, Y. Xu, J. Xiu and S. Zhang, Sol. Energy Mater. Sol. Cells, 2016, 144, 1-6.

29 X. Hu, Z. Huang, X. Yu and B. Li, BioEnergy Res., 2013, 6, 1135-1141.

30 H. Li, R. Wang, H. Hu and W. Liu, Appl. Surf. Sci., 2008, 255, 1894-1900.

31 R. Qin, G. Xu, L. Guo, Y. Jiang and R. Ding, Mater. Chem. Phys., 2012, 136, 737-743.

32 G. Fang, Z. Chen and H. Li, Chem. Eng. J., 2010, 163, 154-159.

33 L. Yuan, G. Liang, J. Xie, L. Li and J. Guo, Polymer, 2006, 47, 5338-5349.

34 C. Alkan, A. Sari and A. Karaipekli, Energy Convers. Manage., 2011, 52, 687-692.

35 Z.-H. Chen, F. Yu, X.-R. Zeng and Z.-G. Zhang, Appl. Energy, 2012, 91, 7-12.
36 B. Li, T. Liu, L. Hu, Y. Wang and L. Gao, ACS Sustainable Chem. Eng., 2013, 1, 374-380.

37 S. Karaman, A. Karaipekli, A. Sari and A. Bicer, Sol. Energy Mater. Sol. Cells, 2011, 95, 1647-1653.

38 D. Yang, S. Shi, L. Xiong, H. Guo, H. Zhang, X. Chen, C. Wang and X. Chen, Sol. Energy Mater. Sol. Cells, 2016, 144, 228-234.

39 C. Liu, Z. Rao, J. Zhao, Y. Huo and Y. Li, Nano Energy, 2015, 13, 814-826.

40 Y. Konuklu and H. O. Paksoy, Energy Technol., 2015, 3, 503508.

41 R. Luo, S. Wang, T. Wang, C. Zhu, T. Nomura and T. Akiyama, Energy and Buildings, 2015, 108, 373-380.

42 B. Zalba, J. M. Marin, L. F. Cabeza and H. Mehling, Appl. Therm. Eng., 2003, 23, 251-283.

$43 \mathrm{X} . \mathrm{Hu}, \mathrm{Z}$. Huang and Y. Zhang, Carbohydr. Polym., 2014, 101, 83-88.

44 A. Sari, C. Alkan and A. N. Ozcan, Energy and Buildings, 2015, 90, 106-113.

45 A. Sari, C. Alkan and A. Altintas, Appl. Therm. Eng., 2014, 73, 1160-1168.

46 D. Djefel, S. Makhlouf, S. Khedache, G. Lefebvre and L. Royon, Int. J. Hydrogen Energy, 2015, 40, 13764-13770.

47 Y. Min, Y. Fang, X. Huang, Y. Zhu, W. Li, J. Yuan, L. Tan, S. Wang and Z. Wu, Appl. Surf. Sci., 2015, 346, 497-502.

48 X. Li, Z. Cao, Z. Zhang and H. Dang, Appl. Surf. Sci., 2006, 252, 7856-7861.

49 R. Wang, H. Li, W. Liu and X. He, Journal of Macromolecular Science, Part A, 2010, 47, 991-995.

50 Y. Xie, C. A. S. Hill, Z. Xiao, H. Militz and C. Mai, Composites, Part A, 2010, 41, 806-819.

51 M. Wang, Y. Hu, J. Han, R. Guo, H. Xiong and Y. Yin, J. Mater. Chem. A, 2015, 3, 20727-20735.

52 X. Cai, D. Fu and A. Qu, J. Wuhan Univ. Technol., Mater. Sci. Ed., 2015, 30, 1234-1239.

53 X.-M. Tong, T. Zhang, M.-Z. Yang and Q. Zhang, Colloids Surf., A, 2010, 371, 91-97. 